\title{
The use of ultrasound in the diagnosis of cystic lesions of the liver and upper abdomen and in the detection of ascites
}

\author{
C. F. McCARThY, ${ }^{1}$ P. N. T. Wells, F. G. M. ROSS, AND A. E. A. READ \\ From the Departments of Medicine, Medical Physics, and Radiodiagnosis, University of Bristol, United Bristol \\ and Southmead Hospitals, Bristol
}

SUMmary The use of ultrasonic A- and B-scans has been evaluated in the diagnosis of fluid-filled lesions in the liver and abdomen, and in the detection of intraperitoneal fluid. Six patients with polycystic livers or suspected polycystic livers, three with solitary cysts, four with liver abscesses, and three with miscellaneous intraabdominal cystic lesions were scanned. The lesions could be clearly distinguished from solid masses by either technique. The presence of as little as 300 to $800 \mathrm{ml}$ of intraperitoneal fluid could be detected by either the A- or B-scan.

Several papers have appeared on the use of ultrasound in the diagnosis of liver disease (for example, Howry, 1965; Holmes, 1966; Schentke and Renger, 1966; and McCarthy, Read, Ross, and Wells, 1967). They indicate shortcomings in its use for the detection of diffuse disease in the liver but when fluidfilled lesions are suspected it may be the method of choice. The ability to distinguish by means of ultrasound between fluid-filled and solid or gaseous structures has also proved useful in establishing the presence of small amounts of ascitic fluid, the diagnosis of which can be extremely difficult when physical examination alone is used. The technique has already been found to be valuable in several diagnostic problems, for example, in the differentiation of renal masses (see Goldberg, Ostrum, and Isard, 1968) but, apart from the report of Wang, Wang, Chang, Kao, Yü, and Chiang (1964), seems to have been little used in studies of the liver.

\section{METHODS}

Ultrasonic A- and B-scans were carried out as described previously (McCarthy et al, 1967; Wells, McCarthy, Ross, and Read, 1969). For the detection of ascitic fluid the patient lay on one side and the probe was held against the most dependent (lowest) part of the abdomen.

A probe of $2 \mathrm{~cm}$ diameter was used, operating at a frequency of $1.5 \mathrm{MHz}$. The swept gain rate was $1.8 \mathrm{~dB}$ $\mathrm{cm}^{-1}$. The scans were generally made during respiratory inspiration, and the scanning time was about 10 seconds. 'Present address: Department of Gastroenterology, Regional Hospital, Ga!way, Ireland.
A pulse repetition frequency of $150 \mathrm{~Hz}$ was used, so that the two-dimensional P-scans each contained about 1,500 lines.

\section{PATIEN IS}

The patients scanned and the clinical problems they presented are indicated in Tables I to IV.

The opportunity was taken to compare the clinical and ultrasonic detection of intraperitoneal fluid by introducing known amounts at the start of peritoneal dialysis or diagnostic pneumoperitoneum. Volumes of 300 to $800 \mathrm{ml}$ of normal saline were introduced. The presence of shifting dullness was the clinical criterion for the detection of fluid. The comparison of clinical and ultrasonic assessments of the presence of fluid is shown in Table V.

\section{SCAN APPEARANCES}

The appearance of the A-scan and the B-scan which can be used to distinguish between a soft tissue structure and a cyst are illustrated in Figure A. These diagrams are for a normal liver and for an abnormal liver containing a solitary cyst; but the basis of the method is the same in other diagnostic situations. At low sensitivity the normal liver sends back no detectable echoes, but at high sensitivity many small echoes arise from within the liver. If the swept gain compensation is accurate these small echoes appear to be quite regularly distributed. However, if the A-scan line passes through a cyst the part of the scan corresponding to the cyst is relatively free from echoes, even at high sensitivity. This is because 
TABLE I

MULTIPLE CYSTS OR SUSPECTED MULTIPLE CYSTS

\begin{tabular}{|c|c|c|c|c|c|}
\hline $\begin{array}{l}\text { Patient } \\
\text { and Fig. No. }\end{array}$ & $\mathrm{Sex}$ & and & Clinical Details & Clinical Problem & Solution to Problem \\
\hline 1 & $\mathbf{M}$ & 58 & $\begin{array}{l}\text { Abdominal pain; } \\
\text { hepatomegaly } 3 \mathrm{~cm} \text {, firm and regular }\end{array}$ & Cause of hepatomegaly & $\begin{array}{l}\text { Ultrasonic scan-multiple cysts } \\
\text { IVP-polycystic kidneys }\end{array}$ \\
\hline 2 & $\mathrm{~F}$ & 60 & $\begin{array}{l}\text { Known polycystic liver. Marked } \\
\text { hepatomegaly, hard and irregular }\end{array}$ & $\begin{array}{l}\text { Liver felt like secondary } \\
\text { deposits }\end{array}$ & $\begin{array}{l}\text { Ultrasonic scan: multiple cysts } \\
\text { Necropsy: polycystic liver disease }\end{array}$ \\
\hline 3 & $\mathbf{F}$ & 52 & $\begin{array}{l}\text { Abdominal pain. Liver enlarged } \\
6 \mathrm{~cm} \text {, firm and irregular }\end{array}$ & Cause of hepatomegaly & $\begin{array}{l}\text { Ultrasonic scan: multiple cysts } \\
\text { IVP: polycystic kidneys }\end{array}$ \\
\hline 4 & $\mathbf{F}$ & 42 & $\begin{array}{l}\text { Known polycystic kidneys. Uraemic } \\
\text { liver, enlarged } 2 \mathrm{~cm} \text {, firm }\end{array}$ & Cause of hepatomegaly & Ultrasonic scan: multiple cysts \\
\hline 5 & $\mathbf{M}$ & 67 & $\begin{array}{l}\text { Haematemesis. Mass both sides } \\
\text { upper abdomen. IVP: polycystic kidneys }\end{array}$ & Cause of haematemesis & $\begin{array}{l}\text { Ultrasonic scan: multiple cysts } \\
\text { Barium meal: duodenal ulcer }\end{array}$ \\
\hline 6 & $\mathbf{M}$ & 52 & $\begin{array}{l}\text { Haematemesis hepatosplenomegaly, } \\
\text { IVP: polycystic kidneys }\end{array}$ & Cause of haematemesis & $\begin{array}{l}\text { Ultrasonic scan: no cysts } \\
\text { Biopsy of liver: congenital hepatic fibro- } \\
\text { sis. Barium meal: oesophageal val ices }\end{array}$ \\
\hline
\end{tabular}

TABLE II

\begin{tabular}{|c|c|c|c|c|}
\hline $\begin{array}{l}\text { Patient } \\
\text { and Fig. No. }\end{array}$ & $\begin{array}{l}\text { Sex and } \\
\text { Age }\end{array}$ & Clinical Details & Clinical Problem & Solution to Problem \\
\hline 7 & M 72 & $\begin{array}{l}\text { Hard mass in epigastrium, moved } \\
\text { with liver on respiration }\end{array}$ & Nature of mass & $\begin{array}{l}\text { Ultrasonic scan: cyst, } \\
\text { aspiration of cyst }\end{array}$ \\
\hline 8 & F 60 & $\begin{array}{l}\text { Abdominal radiograph because of pain } \\
\text { showed partly calcified mass in } \\
\text { right upper abdomen. }\end{array}$ & Solid or cystic mass & $\begin{array}{l}\text { Ultrasonic scan: cyst } \\
\text { It was thought likely that this was a cal- } \\
\text { cified hydatid cyst. }\end{array}$ \\
\hline 9 & F 77 & $\begin{array}{l}\text { Abdominal radiograph because of pain } \\
\text { showed calcified mass in right }\end{array}$ & Solid or cystic mass & $\begin{array}{l}\text { Ultrasonic scan: cyst, } \\
\text { exact nature of cyst not decided }\end{array}$ \\
\hline
\end{tabular}

TABLE III

LIVER ABSCESS

\begin{tabular}{|c|c|c|c|c|c|}
\hline $\begin{array}{l}\text { Patient } \\
\text { and Fig. No. }\end{array}$ & $\begin{array}{l}\text { Sex } \\
\text { Age }\end{array}$ & and & Clinical Details & Clinical Problem & Solution to Problem \\
\hline 10 & $\mathbf{M}$ & 54 & $\begin{array}{l}\text { Abdominal pain and fever; liver } \\
\text { slightly enlarged }\end{array}$ & Abscess or tumour & $\begin{array}{l}\text { Ultrasonic scan: fluid-filled cavity } \\
\text { drainage of abscess }\end{array}$ \\
\hline 11 & $\mathbf{M}$ & 61 & Upper abdomen tender & Cause of fever & $\begin{array}{l}\text { Ultrasonic scan: fluid-filled cavity, } \\
\text { drainage of abscess }\end{array}$ \\
\hline 12 & $\mathbf{M}$ & 73 & Fever; hepatomegaly; $\mathbf{B}_{1,2}-1,000 \mathrm{pg}$ & Cause of fever & $\begin{array}{l}\text { Ultrasonic scan: suggestive of small } \\
\text { cavities in liver. Temperature subsided } \\
\text { with antibiotics and liver size became } \\
\text { normal. }\end{array}$ \\
\hline 13 & $\mathbf{M}$ & 42 & Abdominal pain, tender liver & Cause & $\begin{array}{l}\text { Ultrasonic scan: fluid-filled cavities, } \\
\text { pus aspirated from liver. Fєver and } \\
\text { hepatomegaly went on chloroquine. }\end{array}$ \\
\hline
\end{tabular}

TABLE IV

MISCELLANEOUS

\begin{tabular}{|c|c|c|c|c|}
\hline $\begin{array}{l}\text { Patient No. } \\
\text { and Fig. }\end{array}$ & $\begin{array}{l}\text { Sex and } \\
\text { Age }\end{array}$ & Clinical Details & Clinical Problem & Solution to Problem \\
\hline 14 & F 30 & $\begin{array}{l}\text { Pregnant } 29 / 40 \text {; mass right upper } \\
\text { abdomen }\end{array}$ & Possibly liver tumour & $\begin{array}{l}\text { Isotope scan: liver normal. Ultrasonic } \\
\text { scan: large fluid-filled cavity. IVP: } \\
\text { right hydronephrosis }\end{array}$ \\
\hline 15 & F 5 & $\begin{array}{l}\text { Fever and hard upper abdominal } \\
\text { mass }\end{array}$ & $\begin{array}{l}\text { Possibly liver or pancreatic } \\
\text { tumour }\end{array}$ & $\begin{array}{l}\text { Ultrasonic scan: cystic mass which dis- } \\
\text { appeared after three months and was } \\
\text { probably a pancreatic pseudo-cyst. }\end{array}$ \\
\hline 16 & F 6 & $\begin{array}{l}\text { Anaemia and hepatomegaly; bruit } \\
\text { over liver }\end{array}$ & Cause of hepatomegaly & $\begin{array}{l}\text { Ultrasonic scan: multiple fluid-filled } \\
\text { cavities. Laparotomy: plum-coloured } \\
\text { swellings in liver, } 2-4 \mathrm{~cm} \text { size. } \\
\text { Histolcgy: arteriovenous anastomoses. }\end{array}$ \\
\hline
\end{tabular}




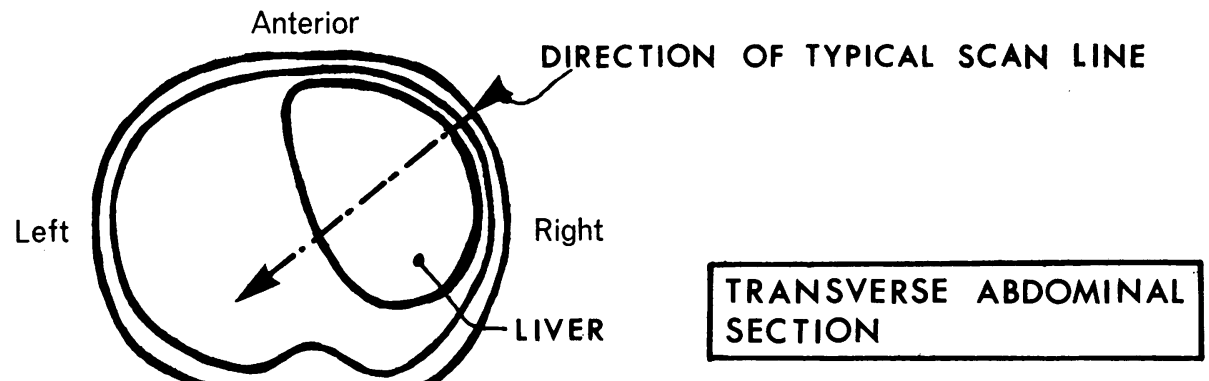

Posterior

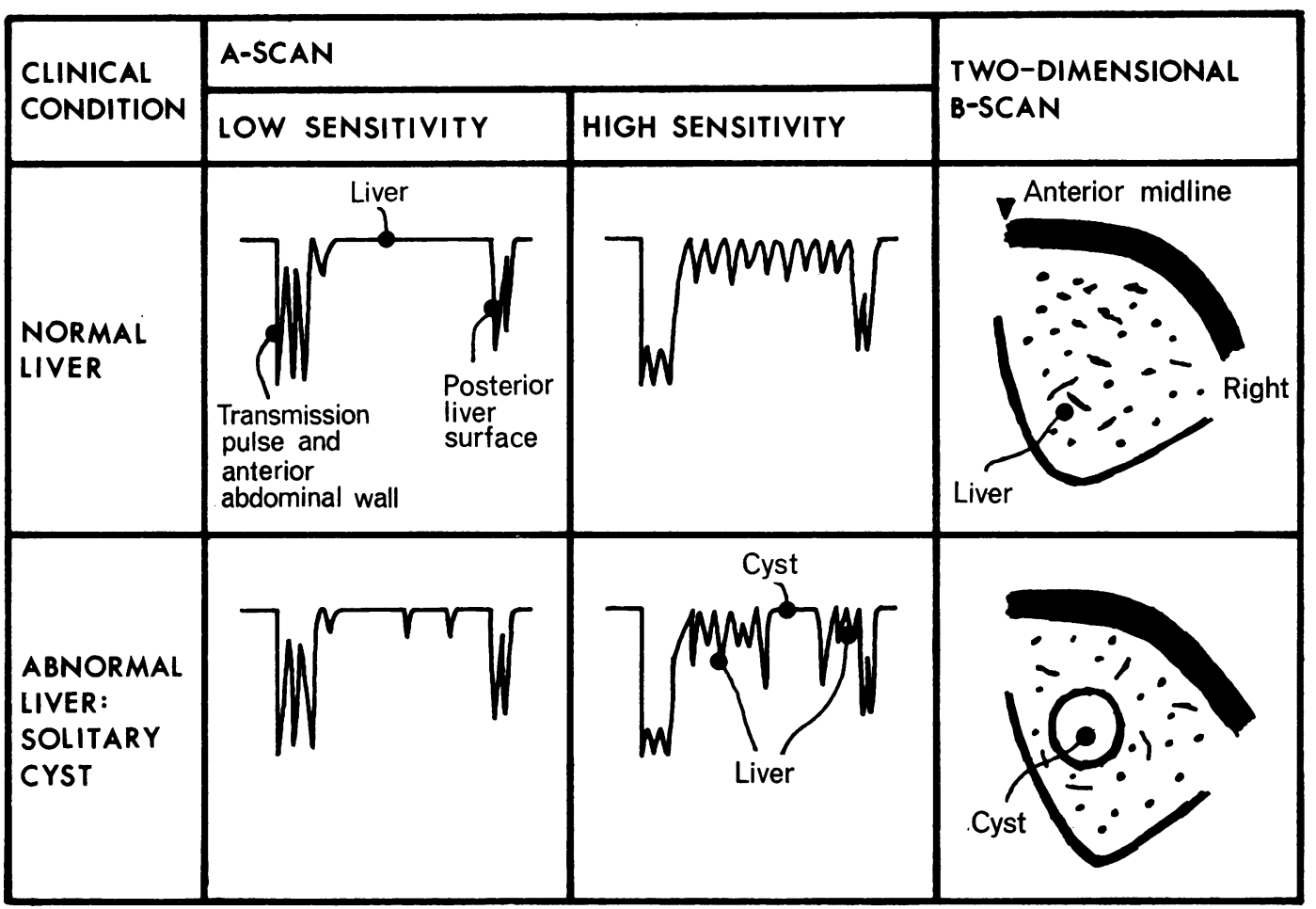

FIG. A. Diagrams illustrating the scan plane, and the appearances of $A$-and B-scans in the normal and in cystic disease.

a solid mass of homogeneous tissue contains small acoustic discontinuities which are not so marked in a liquid.

The B-scan appearance of a cyst or abscess within the liver is of a relatively echo-free area surrounded by echo-producing surfaces. A superficially similar appearance may be seen in some patients with secondary tumour in the liver. In this situation an increase in the sensitivity of the ultrasonic system produces many echoes in the previously echo-free area, whereas a fluid-filled area does not develop so many echoes.
The physical basis of the technique is discussed in greater detail elsewhere (Wells, 1969). Thus, there is a tendency for echoes to appear to originate from within a cystic area when high sensitivity is used, due to reverberation and the increasing width of the ultrasonic beam. Ostrum, Goldberg, and Isard (1967) mention that they use a substantial degree of suppression to eliminate these signals from the display. However, in the A-scans presented here, suppression was kept to a minimum, because its use can lead to confusion between a cyst and, for example, a tumour. The threshold level of the B-scan display introduced 


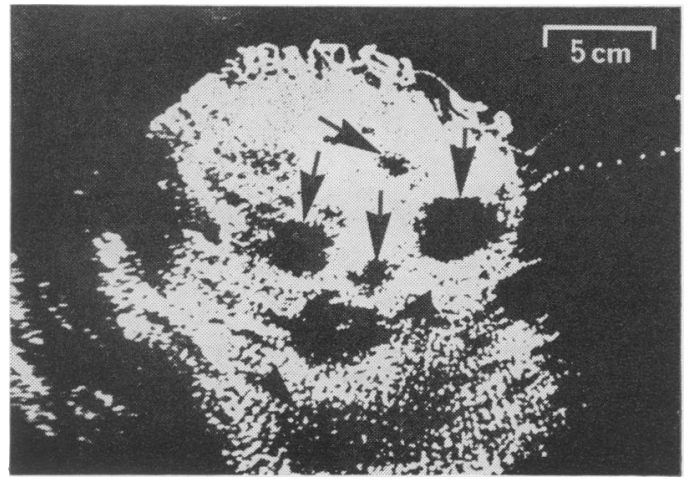

FIG. 1. Polycystic liver disease. The arrows indicate some of the many cysts.

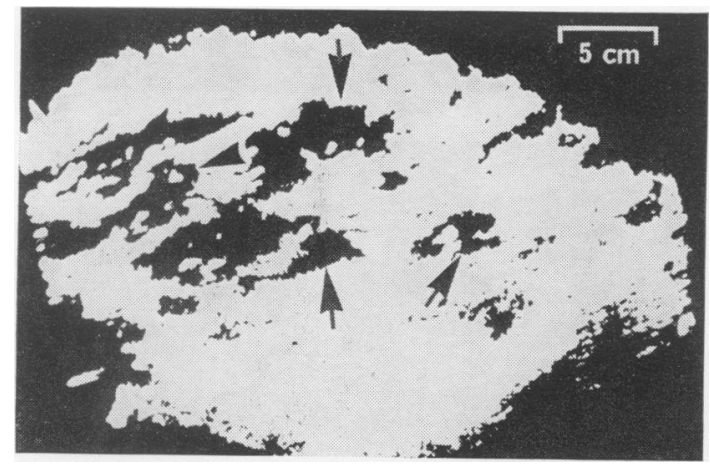

FIG. 2. Polycystic liver disease. The arrows indicate some of the many cysts. (On this occasion the performance of the equipment was not entirely satisfactory.)

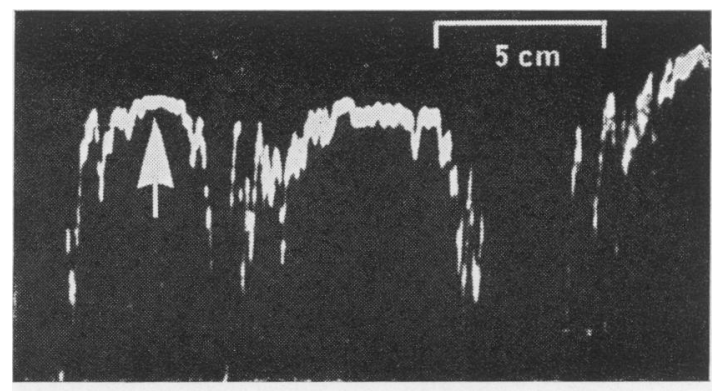

FIG. 4a.

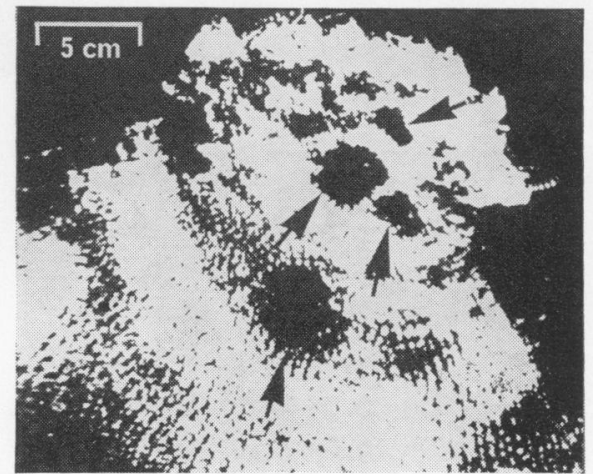

FIG. $4 \mathrm{~b}$.

FIG. 4. Polycystic liver disease. (a) A-scan: (b) two-dimensional B-scan. The arrows indicate some of the many cysts.

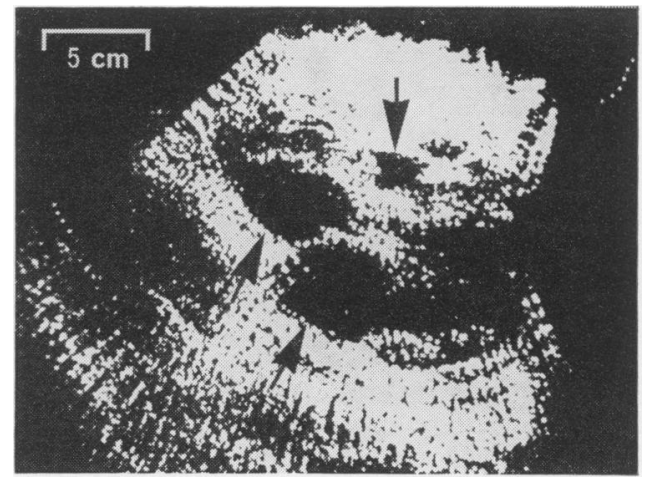

FIG. 5. Polycystic liver disease. The arrows indicate some of the many cysts.

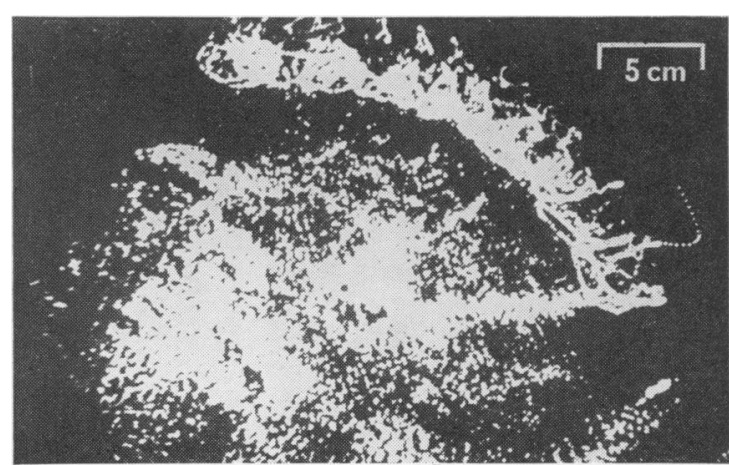

FIG. 6. Congenital hepatic fibrosis. The scan gives no evidence of fluid-filled cavities within the liver. 


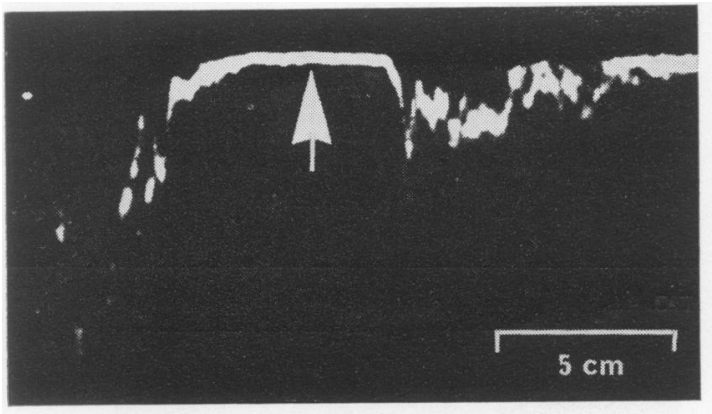

FIG. 7a.

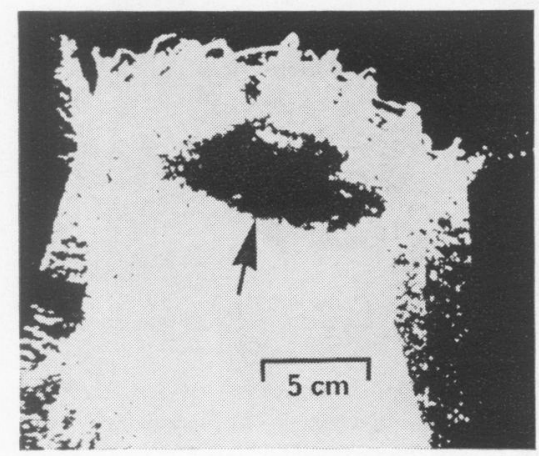

FIG. 7b.

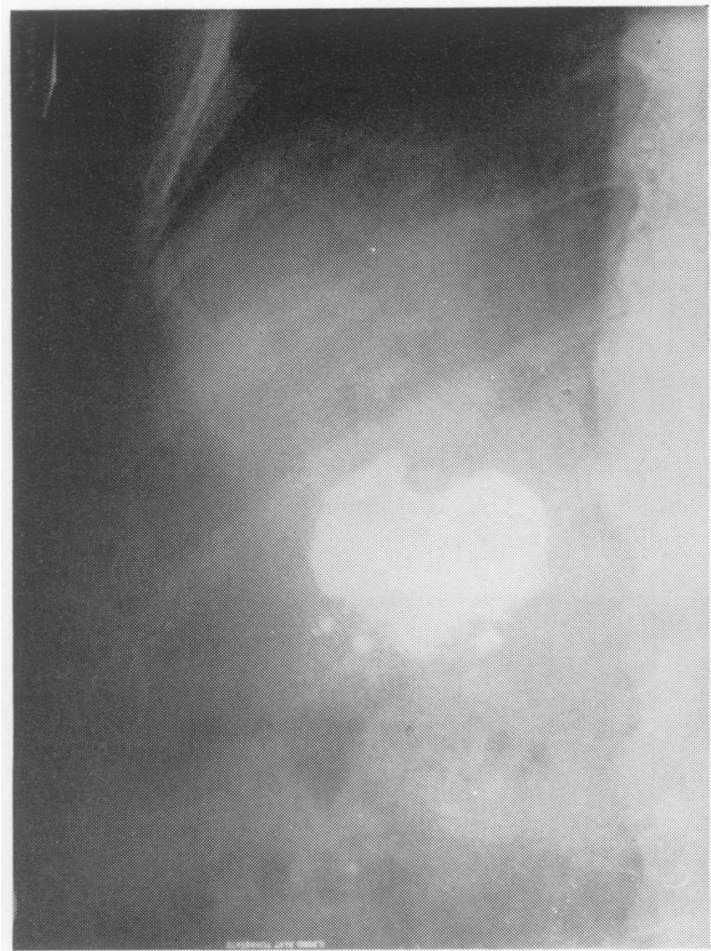

FIG. 7c.

FIG. 7. Solitary cysts. (a) A-scan: (b) two-dimensional B-scan. The arrows indicate the cyst. (c) Radiograph, with cyst demonstrated by Lipiodol.

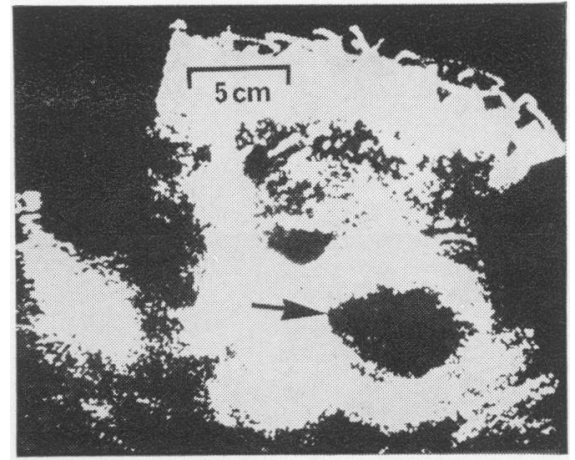

FIG. 8. Probably a calcified hydatid cyst indicated by the arrow.

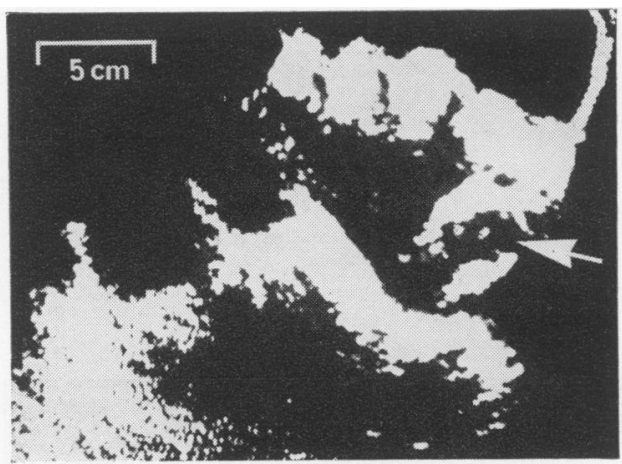

FIG. Ya.

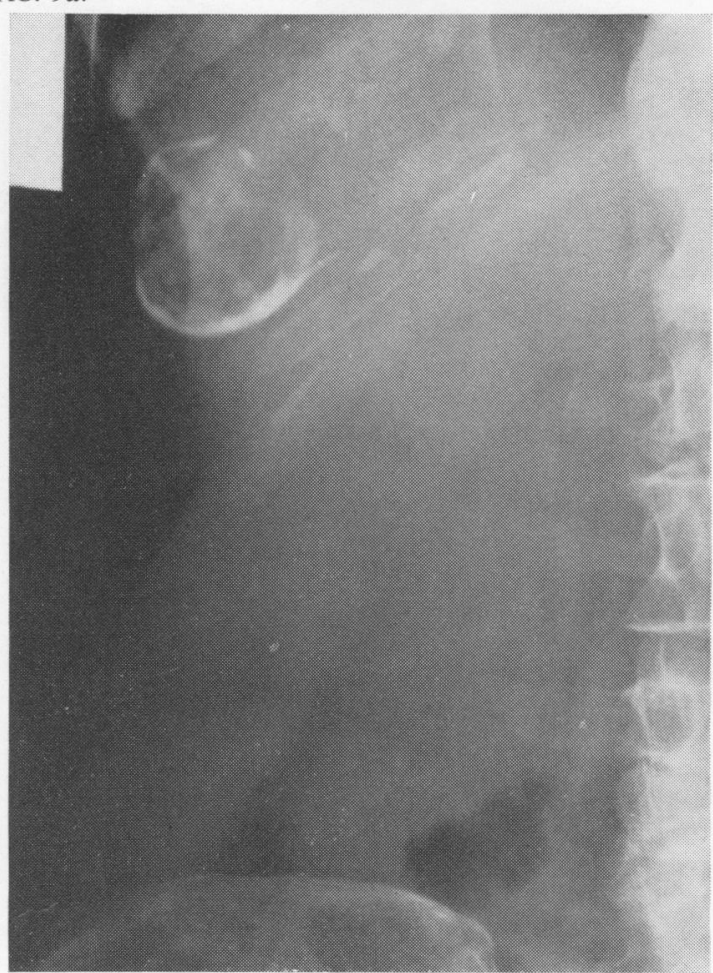

FIG. 9b.

FIG. 9. Solitary cyst; (a) two-dimensional B-scan arrow indicating the cyst and (b) radiograph showing calcified mass. 


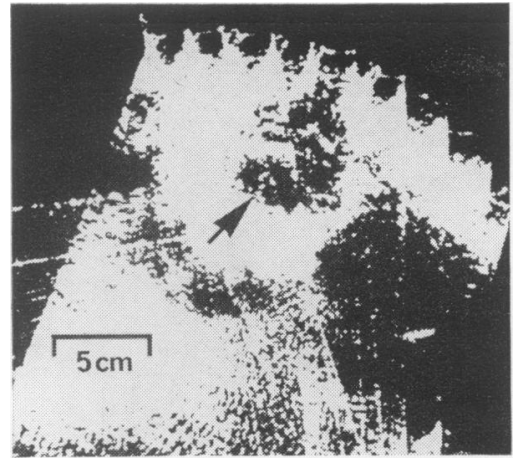

FIG. 10. Liver abscess indicated by the arrow.

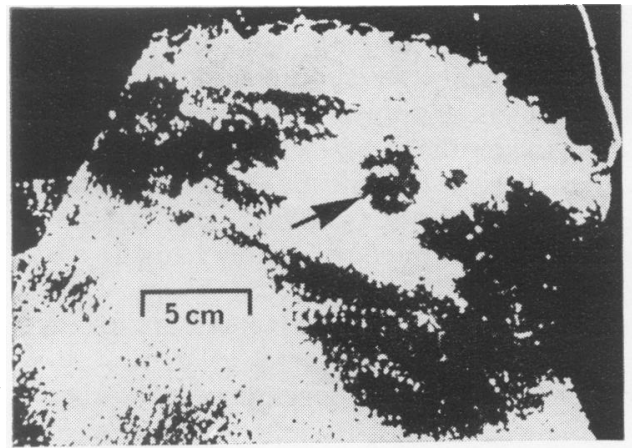

FIG. $11 \mathrm{a}$

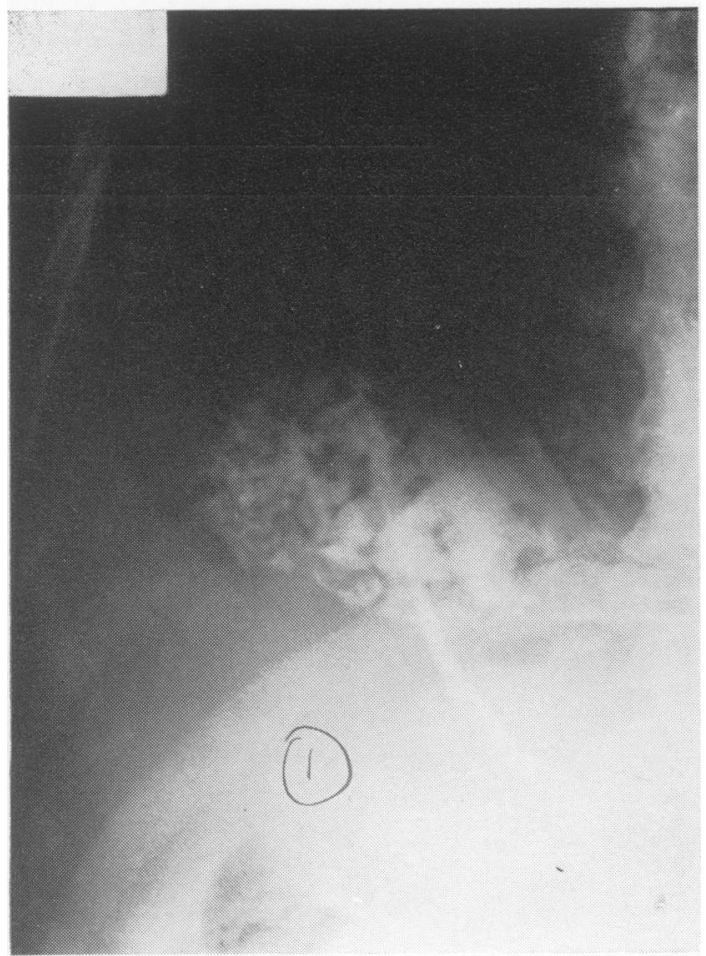

FIG. $11 \mathrm{~b}$

FIG. 11. Liver abscess in case 11: (a) two-dimensional $B$-scan, arrow indicating the abscess and (b) radiograph with abscess demonstrated by Lipiodol.

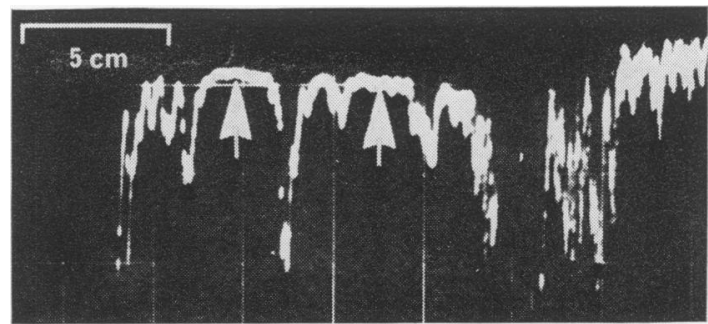

FIG. 12a.

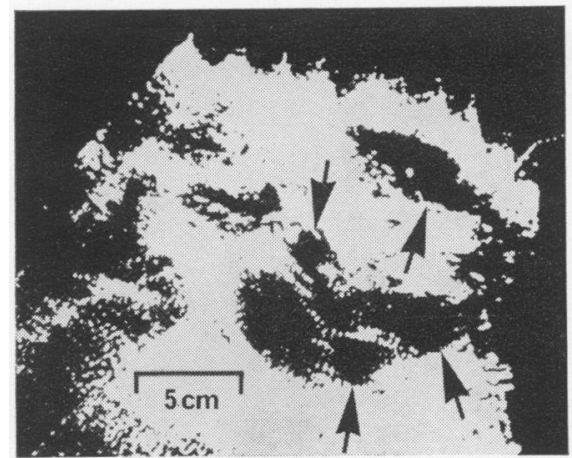

FIG. $12 b$.

FIG. 12. Probably multiple liver abscess. (a) A-scan; (b) two-dimensional B-scan. The arrows indicate some of many cavities, presumably fluid-filled.

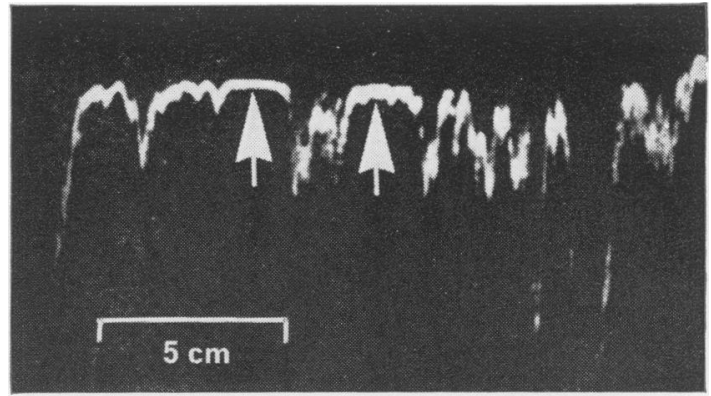

FIG. 13a.

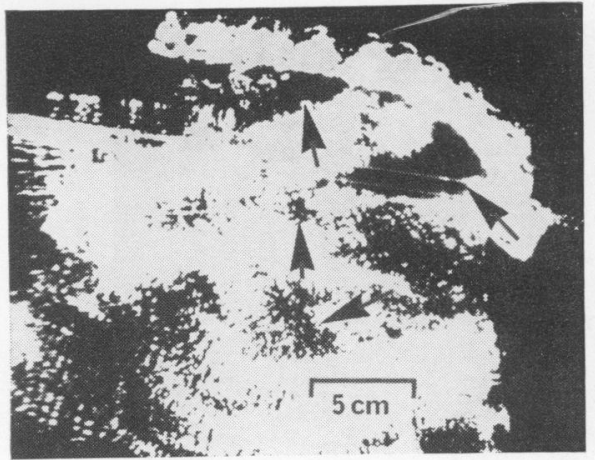

FIG. $13 \mathrm{~b}$.

FIG. 13. Amoebic liver abscess. (a) A-scan; (b) twodimensional B-scan. The arrows indicate some of many fluid-filled cavities. 


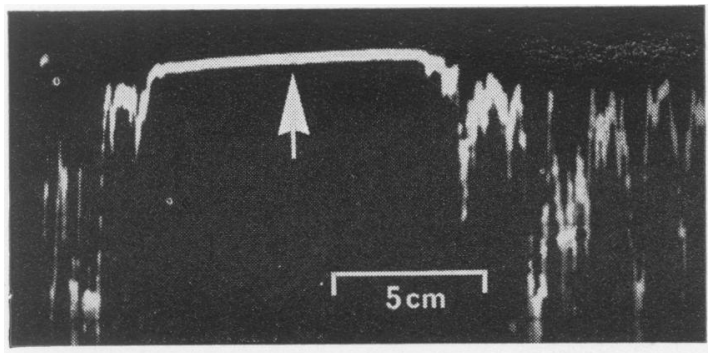

FIG. 14a

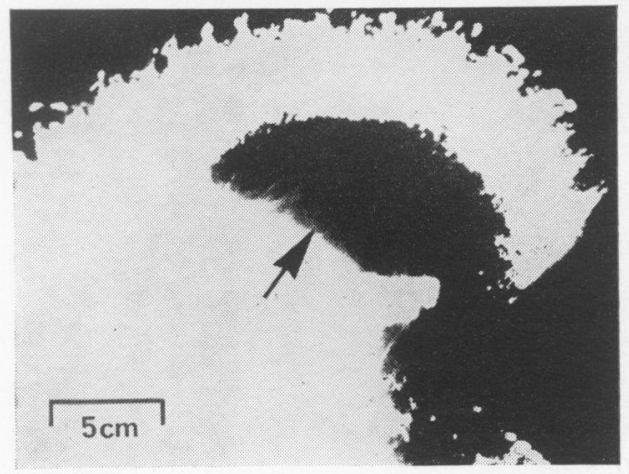

FIG. $14 \mathrm{~b}$.

FIG. 14. Right hydronephrosis. (a) A-scan; (b) two-dimensional B-scan. The arrows indicate the fluid-filled cavity.

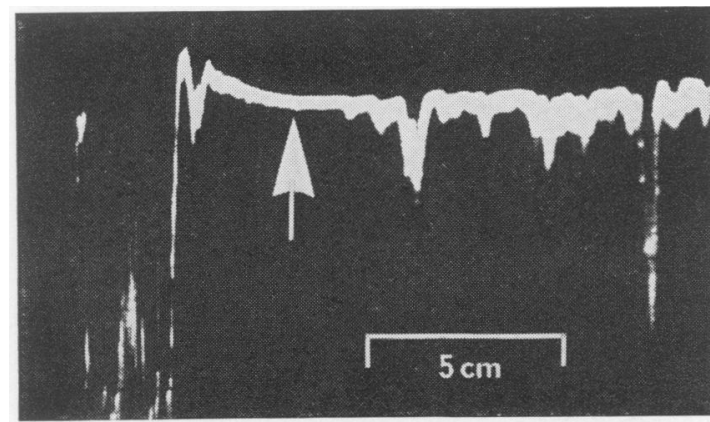

FIG. $15 a$.

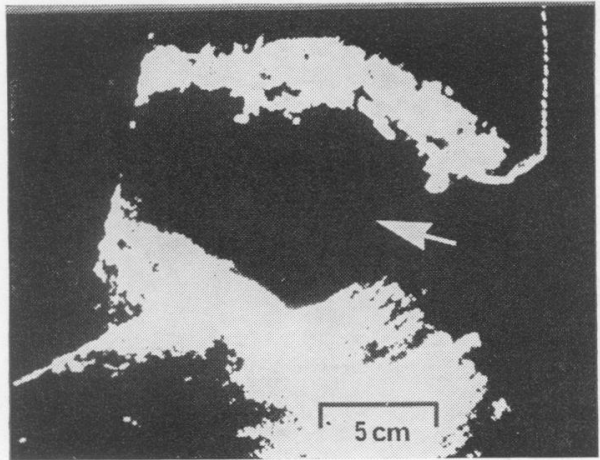

FIG. $15 \mathrm{~b}$

FIG. 15. Probably pancreatic pseudo-cyst. (a) A-scan; (b) two-dimensional B-scan. The arrows indicate the fluid-filled cavity.

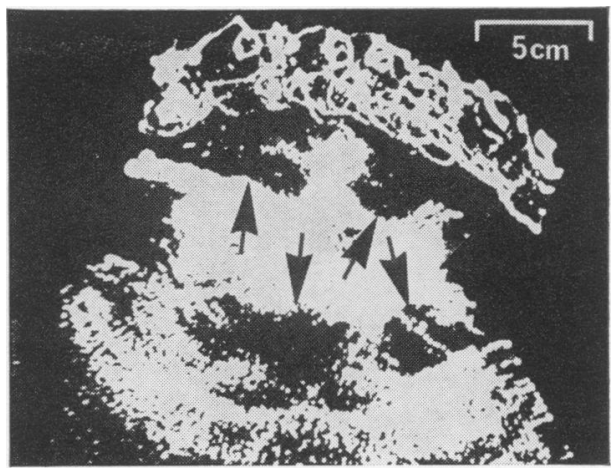

FIG. 16. Arteriovenous anastomoses. The arrows indicate some of many fluid-filled cavities.

an additional degree of suppression in the twodimensional scans, and this must be considered when interpreting the results.

The characteristic diagnostic appearances were obtained in all patients examined, and typical Aand B-scans are illustrated in Figures 1 to 16.

\section{DETECTION OF INTRAPERITONEAL FLUID}

The characteristic B-scan appearance of ascites is shown in Figure 17. From Table V it can be seen that quite small volumes of fluid could be detected both

TABLE V

ETECTION OF INTRAPERITONEAL FLUID

\begin{tabular}{lll} 
Volume $(\mathrm{ml})$ & Detected & \\
\cline { 2 - 3 } & Clinically & Ultrasonically \\
\hline 300 & - & + \\
350 & + & + \\
400 & - & + \\
400 & + & + \\
500 & - & + \\
600 & + & + \\
600 & + & + \\
600 & + & + \\
700 & + & +
\end{tabular}

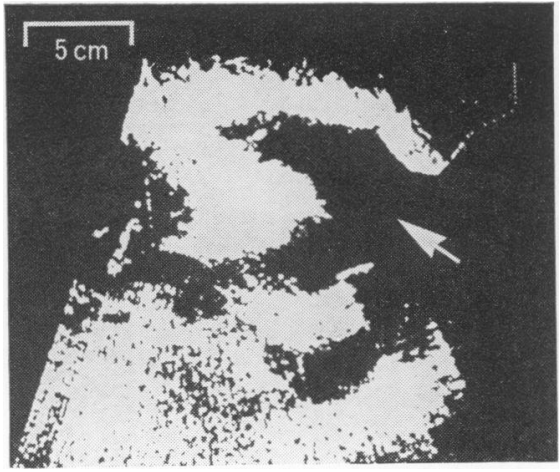

FIG. 17. Ascites. The arrow indicates the region containing fluid. 
by clinical examination and ultrasound. However, in two instances the ultrasonic method detected fluid when it was not demonstrable clinically.

\section{DISCUSSION}

It is apparent from these results that ultrasound is extremely valuable in deciding whether multiple cysts are a cause of hepatic enlargement. In two of the patients with multiple cysts in the liver, the clinical impression when the liver was palpated was that it was replaced by secondary tumour. Ultrasound revealed multiple cysts in those patients in whom there was not a gross degree of hepatomegaly. In patient no. 6 with polycystic kidneys it was felt unlikely that multiple cysts were present in the liver because splenomegaly is unusual in patients with multiple cysts in the liver. Ultrasound demonstrated that cysts were not present, and congenital hepatic fibrosis (the alternative cause of hepatomegaly in patients with polycystic kidneys) was diagnosed. This was confirmed by biopsy and later by necropsy.

Of the patients with solitary lesions in the liver, the scan was most helpful in patient no. 7 , where the clinical diagnosis was a malignant tumour of the liver. In patients nos. 8 and 9, the demonstration of a cystic lesion was helpful as there was a slight possibility that the lesion was a calcified tumour. It seems most likely that these patients had old calcified hydatid cysts.

The scan was of considerable value in making a diagnosis of liver abscess in the four patients described. In patient no. 11, the surgeon at laparotomy doubted the diagnosis as the surface of the liver looked normal but needling it produced pus.

The ultrasonic diagnosis of a fluid-filled lesion in patient no. 14 enabled the surgeon to plan a nephrectomy and avoid a diagnostic laparotomy. In patient no. 15 an operation was avoided because of the information from the ultrasonic scan. In patient no. 16 the most likely clinical diagnosis was cirrhosis, with which the scan was not compatible, and operation confirmed the presence of an arteriovenous malformation.

It is usually considered that clinical detection of ascitic fluid is difficult unless 2 litres of fluid are present (Sherlock, 1968). Undoubtedly the knowledge that fluid has been put into the abdomen influences the observer in eliciting the signs of ascites, and this may account for the detection of shifting dullness when as little as $300 \mathrm{ml}$ was present (see Table V). There is no doubt that an ultrasonic scan can detect smaller amounts than 2 litres of fluid.

From the patients scanned it seems that an ultrasonic scan is helpful in the following clinical situations:
1 If a liver abscess is suspected it is important that many ultrasonic scans are carried out, otherwise the ultrasonic scan plane may not pass through the abscess cavity. It is unlikely that scanning will diagnose an abscess of less than $2 \mathrm{~cm}$ in diameter, but most abscesses at the time of diagnosis are much larger than this. Of the patients reported by Butler and McCarthy (1969), the diameter of the smallest abscess was $6 \mathrm{~cm}$. Wang et al (1964) found that about $14 \%$ of abscesses were $3 \mathrm{~cm}$ or less in diameter. They have extensive experience of the use of ultrasound in the diagnosis of liver abscess; using an A scope they successfully diagnosed about $97 \%$ of 218 patients with abscess.

It is unlikely that an abscess will not be found if the liver is scanned carefully. In five patients scanned by us in whom liver abscess was suspected clinically, the ultrasonic scan did not reveal appearances of fluid and none was later shown to have an abscess. An abscess can be accurately localized by ultrasound and with knowledge of its exact site repeated aspiration and instillation of an antibiotic may avoid the need for formal surgery (McFadzean, Chang, and Wong, 1953). Such localization may also help the surgeon at operation as inspection of the liver may not reveal the site of the lesion. Ultrasound will also demonstrate the gradual closure of an abscess cavity. Scintiscanning of the liver will show an area of decreased uptake if an abscess is present but in contrast to ultrasound will not indicate whether this area of decreased uptake is due to a solid or cystic lesion.

2 If hepatomegaly is present, the demonstration of many cysts may reverse a clinical diagnosis of liver secondaries for a more favourable one of polycystic liver.

3 If there is a localized mass in the liver.

4 If hydatid disease of the liver is suspected.

5 If ascites is suspected. If doubt exists after clinical examination of the abdomen whether or not fluid is present an ultrasonic scan will usually decide the diagnosis. A negative ultrasonic scan does not exclude the possibility of the presence of small amounts of fluid. If a small amount of fluid is present it is helpful if the patient lies on one side and the ultrasonic probe is held against the lowest, most dependent part of the abdomen. The fluid will gravitate towards this point and may then be detected. R.ecently, four-quadrant aspiration of the abdomen in patients with acute abdominal conditions has been considered to be diagnostically helpful (Veith, Webber, Karl, and Deysine, 1967). Small amounts of fluid may be localized with the ultrasonic scan and the need for multiple paracenteses may be reduced.

The simple, relatively inexpensive A-scan equip- 
ment is quite adequate to make the diagnosis although some practice is required in recognizing the appearance of fluid. It is helpful to compare the results of A-scanning with B-scanning until such practice is obtained.

We are grateful to Dr H. F. Freundlich, Head of the Department of Medical Physics, United Bristol Hospitals, who has always supported our work with his enthusiasm. We acknowledge much skill and technical assistance, in particular that of Mr G. P. Garland. We thank the physicians and surgeons of the United Bristol Hospitals and Southmead Hospital for referring their patients to us for scanning.

The work was financed by the Medical Research Council, the Department of Health and Social Security (Health), and the Board of Governors of the United Bristol Hospitals.

\section{REFERENCES}

Butler, T. J., and McCarthy, C. F. (1969). Pyogenic liver abscess. Gut, 10, 389-399.

Goldberg, B. B., Ostrum, B. J., and Isard, H. J. (1968). Nephrosonography: ultrasound differentiation of renal masses. Radiology, 90, $1113-1118$.
Holmes, J. H. (1966). Ultrasonic diagnosis of liver disease. In Diagnostic Ultrasound, pp. 249-263. Edited by C. C. Grossman et al, Plenum Press, New York.

Howry, D. H. (1965). A brief atlas of diagnostic ultrasonic radiologic results. Radiol. Clin. N. Amer., 3, 433-452.

McCarthy, C. F., Read, A. E. A., Ross, F. G. M., and Wells, P. N. T. (1967). Ultrasonic scanning of the liver. Quart. J. Med., 36, 517-524.

McFadzean, A. J. S., Chang, K. P. S., and Wong, C. C. (1953). Solitary pyogenic abscess of the liver treated by closed aspiration and antibodies. Brit. J. Surg., 41, 141-152.

Ostrum, B. J., Goldberg, B. B., and Isard, H. J. (1967). A-mode ultrasound differentiation of soft-tissue masses. Radiology, 88, 745-749.

Schentke, K. W., and Renger, F. (1966). Uber die diagnostische verwertbarkeit des ultraschallhepatogramms. Z. ges. inn. Med., 21, 239-240.

Sherlock, S. P. (1968). In Diseases of the Liver and Biliary System, 4th edition, p. 140. Black'vell, Oxford.

Veith, F. J., Webber, W. B., Karl, R. C., and Deysine, M. (1967), Diagnostic peritoneal lavage in acute abdominal disease. Ann Surg., 166, 290-295.

Wang, H. F., Wang, C. E., Chang, C. P., Kao, J. Y., Yü, L., and Chiang, Y. N. (1964). The application and value of ultrasonic diagnosis of liver abscess. Chin. med. J., 83, 133-140.

Wells, P. N. T. (1969). The Physical Principles of Iltrasonic Diagnosis. Academic Press, London.

-, McCarthy, C. F., Ross, F. G. M., and Read, A. E. A. (1969). Comparison of A-scan and compound B-scan ultrasonography in the diagnosis of liver disease. Brit. J. Radiol. (in press). 